\title{
Effect of Combined Organic and Inorganic Fertilizer on Yield and Yield Components of Food Barley (Hordeum Vulgare L.)
}

\author{
Mestawut Adane $^{1} \quad$ Abebe Misganaw ${ }^{1} \quad$ Getachew Alamnie ${ }^{2}$ \\ 1. Mekdela Amba University, College of Agriculture and Natural Resource, Department of Plant Science \\ 2.Mekdela Amba University, College of Natural and Computational Sciences, Department of Biology
}

\begin{abstract}
Barley is an important food and beverage crop in the highlands of Ethiopia. Despite many importance of barley and its many useful characteristics, there are several factors affecting its production. Low Soil fertility is one of the major constraints affecting its production. Integrated nutrient management, where both natural and man-made sources of plant nutrients are used, is the best approach to supply adequate and balanced nutrients and increase barley productivity in an efficient and environmentally benign manner, without sacrificing soil productivity of future generations. With this in view, integrated applications of organic and inorganic fertilizer sources on yield and yield components of barley were assessed in this review. By this maintaining soil fertility is one of the main factors affecting the sustainability of barley production. The advantages need to be integrated in order to make optimum use of organic and inorganic fertilizer achieve balanced nutrient management for barley yield. This review study showed that balanced fertilization application using both organic and inorganic fertilizers is important for maintenance of yield and yield components of barley. The basic concept underlying the combined applications of fertilizers is the adjustment of soil fertility and plant nutrient supply to an optimum level for sustaining desired barley productivity through optimization of the benefits from all possible sources of plant nutrients in an integrated manner. Therefore, increased attention should be being paid to developing an integrated soil fertility management that maintains or enhances soil productivity through balanced use of all sources of nutrients, including organic and inorganic fertilizers.
\end{abstract}

Keywords: Barley Productivity, Integrated Soil Fertility Management, Nutrient Management, Plant Nutrients

DOI: $10.7176 / \mathrm{FSQM} / 95-01$

Publication date:March $31^{\text {st }} 2020$

\section{Introduction}

Food Barley (Hordeum vulgare L.) is one of the most ancient crops among cereals and has played a significant role in the development of agriculture in the world (Alnarp, 2013). It is one of the most important, economically valuable and widely used cereal crops, which belongs to the family Poaceae with a diploid chromosomes number (Alnarp, 2013). Barley (Hordeum vulgare) ranks fourth among cereals in the world and is grown annually on 48 million hectares in a wide range of environments. Ethiopia is the second largest producer of barley in Africa next to Morocco, accounting for about 26 percent of the total barley production in the country (Shahidur et al., 2015). CSA (2017) reported that barley is the fifth most important cereal crop after teff, wheat, maize, and sorghum in total production in the country.

Barley (Hordeum vulgare) is one of the most important crops for food, feed, malt and income generation for many smallholder farmers in the highlands of Ethiopia (Bayeh Mulatu and Berhane Lakew 2011). Despite its importance and many useful characteristics, there are several factors affecting its production (Melle Tilahun et al., 2015). The most important factors that reduce yield of barley in Ethiopia are poor soil fertility, water logging, drought, frost, soil acidity (low soil $\mathrm{pH}$ ), diseases and insects, poor crop management practices, limited availability of improved varieties and weed competition (Assefa Workineh et al., 2017). Poor soil fertility and use of low yielding varieties are among the most important constraints that threaten barley production in Ethiopia (Paul et al., 2011). Assefa Workineh et al. (2017); Gete Zeleke et al. (2010); Tolera Abera et al. (2011) reported that, soils in the highlands of Ethiopia usually have low levels of essential plant nutrients, especially low availability of nitrogen and it is the major constraint to cereal crop production.

To maximize yield and quality of barley, it has been shown that nutrient management practices should be adjusted according to anticipated availability of nutrients to the crop (Edney et al., 2014). Integrated soil fertility management (ISFM) can give benefit to production and livelihood of farmers; the resilience of cropping system to climate change impacts and mitigation of greenhouse gas from fertilizers and soil (Melle Tilahun et al., 2015).

Getachew Agegnehu et al. (2014) reported that continuous applications of inorganic fertilizers alone resulted in deterioration of soil health in terms of physical, chemical, and biological properties of the soil. Organic fertilizer application has been reported to improve crop growth by supplying plant nutrients including micronutrients as well as improving physical, chemical, and biological properties of the soil, thereby providing a better environment for root development by improving the soil structure (Dejene Kasahun and Lemlem Semungus, 2012). As a result integrated use of organic and inorganic fertilizers for tackling soil fertility depletion and sustainably increasing crop yields had a paramount importance (Gete Zeleke et al., 2010; Getachew Agegnehu and Tilahun Amede, 2017). 
Many research findings have shown that neither inorganic fertilizers nor organic sources alone can result in sustainable productivity (Godara et al., 2012). Integrated soil fertility management involving the judicious use of combinations of organic and inorganic resources is a feasible approach to overcome soil fertility constraints and contribute high crop productivity in agriculture (Abedi et al., 2010; Hintsa Meresa et al., 2016). So the objective of this review is to assess the effect of organic and inorganic fertilizers application on yield and yield components of barley.

\section{Barley Production and Productivity in Ethiopia}

Ethiopia is ranked twenty-first in the world in barley production with a share of 1.2 percent of the world's total production. According to Shahidur et al. (2015) Ethiopia is the second largest producer of barley in Africa next to Morocco, accounting for about 26 percent of the total barley production in the continent. According to these authors, about 4.5 million smallholder farmers grew barley on more than 1 million hectares of land.

\subsection{Integrated Soil Fertility Management (ISFM)}

According to Vanlauwe and Zingare (2011) ISFM was defined as a set of soil fertility management practices that necessarily include the use of fertilizer, organic inputs, and improved germplasm combined with the knowledge on how to adapt these practices to local conditions, aiming at maximizing agronomic use efficiency of the applied nutrients and improving crop productivity. Thus; ISFM includes combination of both organic and inorganic source in a sustainable way to improve crop productivity (Abedi et al., 2010; Hintsa Meresa et al., 2016).

Hintsa Meresa et al. (2016) revealed that Waste lands are converted to high fields on the same lands for many years by using integrated soil fertility management, better use of organic materials available on farm to build up soil organic matter. Vanlauwe et al. (2015) identified that there are considers of the knowledge of farmers towards intensification options in agricultural production including integrated options such as combined use of organic and inorganic inputs, legume-cereal integration through rotations and intercropping, conservation agriculture and agro forestry options.

\subsubsection{Inorganic Fertilizers}

Fertilizers are concentrated sources of essential nutrients in a form that is readily available for plant uptake (Fairhurst, 2012). Abedi et al. (2010) inorganic fertilizers are fertilizers, either natural or manufactured, containing nutrients essential for the normal growth and development of plants. Moreover, the common fertilization system is focused on providing a limited number of macronutrients, while it is scientifically known that plants need at least 13 available minerals in the soil (Atiyeh et al., 2000).

Yoshida et al. (2016) shown that the excessive and unbalanced use of chemical fertilizers in the long run decreases crop yield, biological activity, soil physical properties, and increases accumulation of nitrates and heavy metals and soil acidity. In connection Ghimire et al. (2017) proven that continued use of inorganic fertilizers reduces crop yield due to soil acidification, loss of soil physical and chemical characteristics, and the lack of appropriate micronutrients in these fertilizers.

In contrast to the above discussion, Mekonen Asrat (2005); Rashid et al. (2007) reported that a day to heading was significantly delayed when $\mathrm{N}$ fertilizer was applied at the highest rate for barley production compared to the lowest rate and Minale Liben et al. (2011) and Wakene Tigre et al. (2014) who reported that plant height of barely was increase with increasing rates of $\mathrm{N}$ fertilizer. Also Assefa Workineh et al. (2017) reported that nitrogen increased the number of grains per spike and this parameter is the best indicator of barley response to nitrogen.

In addition inorganic fertilizers stimulate the availability of nutrients in organic manures (Kumar and Sreenivasulu, 2004). Gopinath et al. (2008) who reported that decreased soil pH in plots treated with inorganic fertilizers than those treated with organic manures. Likewise, Wokocha and Sopruchi (2010) reported that the application of mineral fertilizer alone reduced the soil $\mathrm{pH}$ where it was more pronounced under recommended $\mathrm{N}$ dose.

\subsubsection{Organic Fertilizer}

In organic source the nutrient is released at slower rate when compared with mineral fertilizers because to make the nutrient available they should decomposed with microorganisms (Hintsa Meresa et al., 2016). The use of organic source helps to increase crop response to mineral fertilizers, improving moisture ability of soils, adding nutrients that do not contained by mineral fertilizer, creating better rooting environment, replenishing soil organic matter (Fairhurst, 2012). Study indicated that use of organic fertilizers increases soil organic matter, improves microbial activity, and provides both macro- and micronutrients required for the plant in a more efficient way (Angin et al., 2017). Diacono and Montemurro (2011); Fageria (2012) found that soil organic matter (SOM) plays a crucial role in maintaining sustainability of cropping systems by improving soil physical, chemical and biological properties.

\subsubsection{Compost}

Organic matter (compound) introduced with the compost to the soil and produced by the subsequent biological activity work to promote soil aggregation and enhance aggregate stability (Bot, 2005). Regarding to its effect in 
chemical properties of soil, Buzie-Fru (2010) stated that when compost is incorporated in soil there are immediate calculable changes in the concentrations of nutrients trace metals and other chemical compounds. Fijalkowski et al. (2012) discussed the role of compost in changing PH of the soil due to their content of carbonate and organic matter; the carbonate makes rise in PH while the organic matters buffers the system somewhere neutral. It is indicated that regular addition of organic materials, particularly the composted ones, increased soil physical fertility, mainly by improving aggregate stability and decreasing soil bulk density (Diacono and Montemurro, 2011). On the other hand, composts can have direct effects against disease, as well as stimulation of the competing microorganisms and also development of resistance in plants against diseases (Ebrahimi et al., 2018).

\subsubsection{Farm Yard Manure (FYM)}

Organic agriculture is a production system which relies on ecosystem management and ecological processes rather than on the external flow of agricultural inputs (Foissy et al., 2013). Jarvan et al. (2017) reported that FYM is one of the more valuable organic fertilizers maintaining soil fertility in the systems of alternative agriculture. Maintenance and improvement of soil potential fertility are closely related to the maintenance of soil organic matter and organic carbon balance (Baksiene et al., 2014). On organic farms, where the importation of materials to build and maintain soil fertility is restricted, it is important that a balance between inputs and outputs of nutrients is achieved to ensure both short-term productivity and long-term sustainability (Foissy et al., 2013). Farmyard manures are the major source of nutrient supply also on small farm holdings (Fageria, 2012). Ibrawuchi et al. (2007) reported that the application of FYM in soil modified the $\mathrm{pH}$ of soil from acidic condition to neutral.

\subsubsection{Green Manuring}

Green manure is a type of cover crop grown primarily to add nutrients and organic matter to the soil. Pandey and Singh (2016) defined green manuring as a practice of ploughing or turning into the soil un-decomposed green plants or their residue for the purpose of improving physical structure and fertility of a soil. Complete dependence on chemical fertilizers is making the soil unfertile and less productive in absence of organic material besides soils (Nayak and Vaidya, 2018). A green manure crop is grown for specific period of time and then ploughed under and in corporate in the soil (Hintsa Meresa et al., 2016). A green manure is a crop used primarily as a soil amendment and a nutrient source for subsequent crops (Cherr et al., 2006). Zaccheo (2016) indicated that the practice of green manure provides many improvements in chemical, physical and biological characteristics, through increases in organic matter content and microbial activity, nutrient cycling, disruptions of compacted layers, decreased erosion, incidence of pests and diseases, and suppression of weed plants for sustainable fruit production system.

\subsection{Integrated Effect of Organic and Inorganic Fertilizers on Food Barley Production}

Integrated plant nutrient management is the application of inorganic fertilizer in combination with organic fertilizer to maintain soil fertility and to balance nutrient supply in order to boost up the crop yield per unit area (Roberts, 2010). Emerging evidence indicated that integrated nutrient management involving the judicious use of organic and inorganic resources is a feasible approach to overcome soil fertility constraints (Abedi et al., 2010). Kaur et al. (2008) stated that a judicious combination of organic amendments and inorganic fertilizers is widely recognized strategy of integrated nutrient management to sustain agronomic productivity and improve soil fertility. Arif et al. (2014) stated, the higher yield obtained with integrated use of organic manure and inorganic fertilizers was attributed to increased nutrient availability and uptake, resulting in greater number of fertile tillers, number of grains per panicle, number of panicles per hill, filled grains per panicle, 1000 grain weight, biological yield, grain yield and harvest index. Also Tolera Abera et al. (2018) who reported significantly higher grain yield and biomass yield of barley were obtained with the application of sole recommended NP and the integrated use of 50: 50\% vermin compost and conventional compost with recommended NP.

Getachew Agegnehu et al. (2016); Assefa Workineh (2015) revealed that integrated use of organic and inorganic fertilizers resulted in yield benefits greater than using them alone. The improved yields of barley due to combined application of organic and mineral amendments resulted from positive changes to the soil, including increased soil $\mathrm{pH}$, available $\mathrm{P}$ and total $\mathrm{N}$, and possibly other macro- and micronutrients (Kassu Tadesse et al., 2018).

Hence, under low soil fertility condition, integrated application of organic and mineral fertilizers is highly required because of their additive effects (Getachew Agegnehu et al. 2016; Liu et al. 2012). According to Woubshet Demissie et al. (2017); Mitiku Woldesenbet et al. (2014), the number of productive tillers of barley $\mathrm{m}^{-2}$ was improved with integrated application of organic and mineral fertilizers and indicated that the smallest numbers of tillers per plant could be attributed to the limited supply of plant nutrition from compost and/or FYM at the initial stages of growth.

\subsubsection{Barley Growth Parameters}

Plant Height: Woubshet Demissie et al. (2017) found significantly higher plant height of barley with the integrated application of organic and inorganic fertilizers in Wolmera district. Correspondingly, Mitiku Woldesenbet et al. (2014) found a significant effect of combined application of organic and inorganic fertilizers on plant height barley at Adiyo and Ghimbo with the application of $5 \mathrm{t} \cdot \mathrm{ha}^{-1}$ farmyard manure $+75 \%$ of 
recommended NP and $5 \mathrm{t} \cdot \mathrm{ha}^{-1}$ vermicompost and $75 \%$ of recommended NP. Likewise, Getachew Agegnehu (2009) reported that the use of organic manures in combination with mineral fertilizers maximized the plant height of barley.

\subsubsection{Phenological Parameters of Barley}

Days to 50\% Emergence: The mean day to 50\% emergence of barley is significantly affected by application of sole and integrated organic and inorganic fertilizer (Tariku Beyene et al., 2018). The minimum (5) and maximum (6) days to $50 \%$ emergence of barley were obtained by $100 \%$ NPS and control. Because of, the chemical fertilizer was increased the reaction of germination and emergence than $0 \%$ treatments (Tariku Beyene et al., 2018). Similarly, Tisdale et al. (2002) reported that application of fertilizer near the seeds at the time of planting has the added advantage of stimulating seed germination and seedling emergence.

Days to 50\% Heading: Longer (77) days to 50\% heading of barley was observed under non-fertilized plots (Tariku Beyene et al., 2018). This is in agreement with the research result of Manna et al. (2005) who reported that combined application of NP and organic fertilizers promoted vegetative growth, leading to prolonged days to heading. The mean days to $50 \%$ heading of barley was significantly affected by application of integrated nutrient management (Tariku Beyene et al., 2018). Likewise, Ofosu and Leitch (2009) reported the application of fertilizers of any source, regardless of their doses accelerated days to heading as compared to no fertilizer application. Similarly, Abdur and Khan (2008) reported that NP application significantly affects days to heading of barley. Days to 90\% Maturity: Woinshet Tamiru (2007) reported that N delays maturity. The application of integrated nutrient significantly affected the number of days to $90 \%$ maturity of barley (Tariku Beyene et al., 2018). The higher amount of chemical fertilizer applied, the lower days to maturity. Similarly, Lelissa Gurmessa (2002) found the number of days required to reach physiological maturity by the plants was also decreased with increasing rates of applied organic and inorganic fertilizers

\subsubsection{Yield and Yield Components of Barley}

Spike Length: Application of inorganic and organic fertilizer alone or integrated were produced taller spike length of barley (Tariku Beyene et al., 2018). Getachew Agegnehu et al. (2016) found that the integrated application of organic fertilizer with $\mathrm{N}$ fertilizer rate significantly improved productive tillers of barley at Holetta and Robgebeya. Likewise, the application of $5 \mathrm{t} \cdot \mathrm{ha}^{-1} \mathrm{FYM}$ combined with $75 \%$ inorganic NP gave the highest number of productive tiller $\mathrm{m}^{-2}$ (Mitiku Woldesenbet et al., 2014). Kumar (2009) reported that the number of total tillers was significantly increased with the application of nitrogen fertilizer.

Arif et a1. (2006) reported significant increase in number of grains per spike of barley by applying manure and mineral fertilizer in combination as compared to inorganic fertilizer alone. Also, Sepat et al. (2010) reported spikes density variety were higher in organically managed field than as well as increases in spike per plant could be the consequence of the increase in number of tillers per plant.

Effective Tillers: The attainment of higher number of effective tillers might be due to the synergetic combination effects of organic and inorganic fertilizers (Wubshet Demissie et al, 2017). This is consistent with Mitiku Woldesenbet et al. (2014) who observed that application of $5 \mathrm{t} \mathrm{ha}^{-1}$ farmyard manure along with $75 \%$ of recommended NP gave highest number of productive tillers $\mathrm{m}^{-2}$ and highest number of grains per spike at Adiyo and Ghimbo, respectively.

Number of Kernel: The mean number of kernel per plant was significantly affected by application of NPS and FYM and result the applied treatment indicated integrated nutrient management (Tariku Beyene et al., 2018). According to Tariku Beyene et al. (2018) applications of sole and integrated nutrient management were produced higher number of kernel plant ${ }^{-1}$ as compared to non-fertilized. Likewise, application of $5 \mathrm{t} \mathrm{ha}^{-1} \mathrm{FYM}_{\mathrm{M}}$ combined with 75\% inorganic NP gave the highest number (37 and 36.7) of grain number spike ${ }^{-1}$ (Mitiku Woldesenbet and Tamado Tana (2014). Similarly, Arif et al. (2006) have reported significant increases in the number of grain spike $\mathrm{e}^{-}$ ${ }^{1}$ by applying both organic manures and inorganic fertilizer applications. Godara et al. (2012) reported neither inorganic fertilizers nor organic sources alone can result in sustainable productivity. Therefore, a combination of both inorganic and organic fertilizers, where the inorganic fertilizer provides readily available nutrients and the organic fertilizer mainly increases soil organic matter and improves soil structure and buffering capacity of the soil (Tariku Beyene et al., 2018).

Thousand Seed Weight: Higher 1000 seed weight was obtained from sole and integrated nutrient application as compared to non-fertilized (Tariku Beyene et al., 2018). Similarly, Saidu et al. (2012) also obtained the highest 1000 grain weight, from application of $5 \mathrm{t} \mathrm{ha}^{-1} \mathrm{FYM}$ in combination with 50\% inorganic NP while the lowest 1000 grain weight was recorded from no fertilizer application. Non-significantly lower thousand seed weight of barley was obtained from sole application of NPS and FYM as compared to integrated nutrient management (Tariku Beyene et al., 2018). Godara et al. (2012) concluded that neither inorganic fertilizers nor organic sources alone can result in sustainable productivity. This justifies integrated application of inorganic and organic fertilizers had considerable contribution for thousand seed weight of barley, which might be due higher nutrient concentration both fertilizer sources when integrated. Combination organic and inorganic fertilizers increased thousand seed weight from $10 \mathrm{~g}$ to $44 \mathrm{~g}$ (Woubshet Demissie et al, 2017). 
Dry Biomass Yield: A study reported by Tariku Beyene et al. (2018) found that the dry biomass yield of barley was significantly affected by application of integrated nutrient management and the highest $15917 \mathrm{~kg} \mathrm{ha}^{-1} \mathrm{dry}$ biomass barley was obtained with integrated application of 66.6:33.4\% NPS: FYM. Likewise, the application of $5 \mathrm{t} \mathrm{ha}^{-1}$ FYM in combination with 75\% inorganic NP gave the highest biomass yield of 8259 and $8065 \mathrm{~kg} \mathrm{ha}^{-1}$ of barley at Adiyo and Ghimbo, respectively (Mitiku Woldesenbet and Tamado Tana, 2014). The lowest (5396 kg ha-1) dry biomass yield of barley was obtained from non-fertilized followed $8684 \mathrm{~kg} \mathrm{ha}^{-1}$ by application $100 \%$ of FYM (Tariku Beyene et al., 2018). The use of combined applications of organic and inorganic fertilizers can be kept at optimum level of dry biomass yield (Saidu et al., 2012). Furthermore, Shiferaw Bokore and Anteneh Fikadu, (2014) found that application of all combinations of fertilizers, either alone or combined, significantly increased barley yield over untreated control.

Grain Yield: According to Tariku Beyene et al. (2018) higher (6496 kg ha-1) grain yield was obtained from application of integrated nutrient application (66.6:33.4\% NPS: FYM). Similarly Mitiku Woldesenbet et al. (2014) who reported application of inorganic fertilizers (NP or NPK) with FYM gave a better yield of barley than the application of $100 \%$ inorganic fertilizers alone. Likewise, increase in grain yield by combination of both inorganic and organic fertilizers, where the inorganic fertilizer provides readily available nutrients and the organic fertilizer mainly increases soil organic matter and improves soil structure and buffering capacity of the soil (to holding water capacity, to control soil erosion, to keep soil moisture, to control soil cracking and drying then soil come to rehabilitation) (Godara et al., 2012). Equally, Farah et al. (2014) found higher yield with integrated use of chemical and organic fertilizers as compared to sole chemical fertilizer and have demonstrated the beneficial effect of integrated nutrient management in justifying the deficiency of several macro and micro-nutrients which affected the grain yields.

Application of organic fertilizer with inorganic fertilizer could directly increase yield, improve soil fertility status, and reduce the cost production. improved yields of barley due to combined application of organic and mineral amendments resulted from positive changes to the soil, including increased soil $\mathrm{pH}$, available $\mathrm{P}$ and total $\mathrm{N}$, and possibly other macronutrients and micronutrients (Kassu Tadesse et al., 2015; Getachew Agegnehu et al., 2016).

\section{Conclusion}

Organic fertilizers enhance effect use of inorganic fertilizers and it also reported that integrated use of organic residues with inorganic one helps to reduce the cost. Furthermore, use of inorganic soil ameliorates in conjunction with slow release mineral has the advantages of increasing the nutrient storage capacity of the soil. In developing countries like Ethiopia with low input utilization of fertilizers, integrated use of organic and inorganic fertilizers can be a solution. Therefore, by integrating inorganic fertilizers and organic fertilizers which are available or prepared by using local material yield increment can be attained with sustainable soil fertility management. Future research could be give due attention to developing an integrated plant nutrition system that maintains or enhances soil productivity through balanced use of all sources of nutrients, including chemical fertilizers, organic fertilizers and bio fertilizers. The integrated use of inorganic NP with organic fertilizer sources significantly improved yield and yield components of barley.

\section{References}

Abdur R and Khan RU. 2008. Comparative effect of varieties and fertilizer levels on barley (Hordeum vulgare). International Journal of Agriculture and Biology; 10: 124-126.

Abedi, T., Alemzadeh, A., Kazemeini, S. A. 2010. Effect of organic and inorganic fertilizers on grain yield and protein banding pattern of wheat. Australian journal of crop science; 4(6):384-389.

Alnarp. 2013. Doctoral Thesis on Barley Genetic Resources Swedish University of Agricultural Sciences. Access date $05 / 02 / 2019$.

Angin, I., Aslantas, R., Gunes, A., Kose, M., Ozkan, G. 2017. Effects of sewage sludge amendment on some soil properties, growth, yield and nutrient content of raspberry (Rubus idaeus L.). Erwerbs-obstbau; 59(2):93-99.

Arif M, Ali S, Khan A, Jan T, Akbar M. 2006. Influence of farm yard manure application on various wheat cultivars. Sarhad Journal of Agriculture; 22:27.

Arif, M., Tasneem, M., Bashir, F., Yaseen, G., Iqbal, R. M. 2014. Effect of integrated use of organic manures and inorganic fertilizers on yield and yield components of rice. Journal of Agricultural Research; 52(2):197206.

Assefa Fenta, Maqsood, M., Akbar, M. and Yousaf, N. 2017. Effect of urea fertilizer on growth response of food barley. International of Journal Agricultural Biology; 1: 359-360.

Assefa Workineh. 2015. Response of barley (Hordium vulgare L.) to integrated cattle manure and mineral fertilizer application in the vertisol areas of south Tigray, Ethiopian Journal of Plant Science; 3(2):71-76.

Atiyeh, R. M., Subler, S., Edwards, C. A., Bachman, G., Metzger, J. D., Shuster, W. 2000. Effects of vermicomposts and composts on plant growth in horticultural container media and soil. Pedobiologia, 44(5), 
$579-590$

Baksiene, E., Razukas, A., Repeekiene, J., Titova, J. 2014. Influence of different farming systems on the stability of low productivity soil in Southeast Lithuania. Zemdirbyste-Agriculture; 101(2):115-124.

Bayeh Mulatu, Berhane Lakew. 2011. Barley research and development in Ethiopia an overview. In: Mulatu B, Grando S (eds) Barley research and development in Ethiopia. Holeta, Ethiopia; 1-16.

Bot, A., and Benites, J. 2005. The importance of soil organic matter: Key to drought-resistant soil and sustained food production (No. 80). Food and Agriculture Organization.

Buzie-Fru, C. A. 2010. Development of a continuous single chamber vermicomposting toilet with urine diversion for on-site application.

Cherr, C. M., Scholberg, J. M. S., McSorley, R. 2006. Green manure approaches to crop production. Agronomy Journal; 98(2):302-319.

CSA (Central statistical agency) agricultural sample survey. 2017. Report on area and production of major crops (private peasant holdings, Meher season). Volume I, Statistical bulletin, Addis Ababa, Ethiopia: 10-12.

Dejene Kasahun and Lemlem Semungus. 2012. Integrated agronomic crop managements to improve tef productivity under terminal drought. pp. 235-254. In: I. Md. M. Rahman and H. Hasegawa, (eds.), Water Stress, In Technology Open Science.

Diacono, M., and Montemurro, F. 2011. Long-term effects of organic amendments on soil fertility. In Sustainable Agriculture Volume 2 (pp. 761-786). Springer, Dordrecht.

Ebrahimi, E., Werren, D., und Niemsdorff, P. V. F. 2018. Suppressive effect of composts from residual biomass on Pythium ultimum. Journal of Plant Diseases and Protection; 125(5):443-449.

Edney, M., MacLeod, A. and LaBerge, D. 2014. Evolution of a quality testing program for improving malting barley in Canada. Canadian Journal of Plant Science, 94: 56-62.

Fageria, N. K. 2012. Role of soil organic matter in maintaining sustainability of cropping systems. Communications in Soil Science and Plant Analysis; 43(16):2063-2113.

Fairhurst, T. 2012. Handbook for integrated soil fertility management. Technical Centre for Agricultural and Rural Cooperation.

Farah GA, Dagash YMI, Yagoob SO. 2014. Effect of Different Fertilizers (Bio, Organic and Inorganic Fertilizers) on Some Yield Components of Rice (Oryza Sativa L.). Universal Journal of Agricultural Research; 2:6770 .

Fijakowski, K., Kacprzak, M., Grobelak, A., Placek, A. (2012). The influence of selected soil parameters on the mobility of heavy metals in soils. 15, 81-92.

Foissy, D. Vian, J. F., David, C. 2013. Managing nutrient in organic farming system: reliance on livestock production for nutrient management of arable farmland. Organic agriculture; 3(3-4):183-199.

Getachew Agegnehu and Tilahun Amede. 2017. "Integrated soil fertility and plant nutrient management in tropical agro-ecosystems: a review," Pedosphere, vol. 27, no. 4: 662-680.

Getachew Agegnehu, Paul Nelson, Bird M. I. 2016. "Crop yield, plant nutrient uptake and soil physicochemical properties under organic soil amendments and nitrogen fertilization on Nitisols." Soil Tillage Research; 160:1-13.

Getachew Agegnehu. 2009. "Ameliorating effects of organic and inorganic fertilizers on crop productivity and soil properties on reddish-brown soils," in Proceedings of 10th Conference of the Ethiopian Society of Soil Science,127-150, EIAR, Addis Ababa, Ethiopia, March 2009.

Getachew Agegnehu., C. van Beek, and I. B. Michae. 2014. "Influence of integrated soil fertility management in wheat and teff productivity and soil chemical properties in the highland tropical environment," Journal Soil Sciences Plant Nutrition; 14:532-545.

Gete Zeleke, Getachew Agegnehu, Dejene Abera, and Shahidur R. 2010. Fertilizer and Soil Fertility Potential in Ethiopia: Constraints and Opportunities for Enhancing the System, IFPRI, Addis Ababa, Ethiopia.

Ghimire, R., Lamichhane, S., Acharya, B. S., Bista, P., Sainju, U. M. 2017. Tillage, crop residue, and nutrient management effects on soil organic carbon in rice-based cropping systems: A review. Journal of integrative agriculture; $16(1): 1-15$.

Godara AS, Gupta US, Singh R. 2012. Effect of integrated nutrient management on herbage, dry fodder yield and quality of oat (Avena sativa L.). Forage Research; 38: 59-61.

Gopinath, K.A., Saha, S., Mina, B.L., Pande, H., Kundu, S \& Gupta, H.S. 2008. Influence of organic amendments on growth, yield and quality of wheat and on soil properties during transition to organic production. Nutrient Cycling in Agro-ecosystem; 82: 51-60.

Hintsa Meresa, Zelalem Mengistu, Misene Bisetegn. 2016. Effects of Integrated Soil Fertility Management on Sustainable Crop Production. Journal of Economics and Sustainable Development; 7(1): 25-30.

Ibrawuchi, I.I., Opara, F.A., Tom, C.T Obiefuna, J.C. 2007. Graded replacement of inorganic with organic manure for sustainable maize production in Owerri Imo State, Nigeria. Life Science Journal; 4 (2): 82-87.

Jarvan, M., Vettik, R., Tamm, K. 2017. The importance and profitability of farmyard manure application to an 
organically managed crop rotation. Zemdirbyste Agriculture; 104(4).

Kassu Tadesse, Asrat Mekonnen, Almaz Admau. 2018. "Malting barley response to integrated organic and mineral nutrient sources in Nitisol." International Journal of Recycling of Organic Waste in Agriculture; 7(2):125-134.

Kaur, T., Brar, B. S., Dhillon, N. S. 2008. Soil organic matter dynamics as affected by long-term use of organic and inorganic fertilizers under maize-wheat cropping system. Nutrient Cycling in Agro ecosystems; 81(1):59-69.

Kumar A. 2009. "Response of wheat cultivars of nitrogen fertilization under late sown condition." Indonesian Journal Agronomy; 30(4): 464-467.

Kumar, B. Vijay and M. Sreenivasulu. 2004. "The Hindu”, Online edition of India's National Newspaper. Thursday, Aug 12, 2004.

Lelissa Gurmessa. 2002. Response of Wheat (Tritium arstiuum L.) to Fertilizer N and P in Borana Zone, Ethiopia. (Doctoral Dissertation, MSc Thesis in Agriculture (Agronomy), Alemaya University, Ethiopia).

Liu J, Schulz H, Brandl S, Miehtke H, HuweB Glaser B. 2012. Short-term effect of biochar and compost on soil fertility and water status of a Dystric Cambisol in NE Germany under field conditions. Journal of Plant Nutrition and Soil Science; 175:698-707.

Manna MC, Swarup A, Wanjari RH, Ravankar HN, Mishra B. 2005. Long-term effect of fertilizer and manure application on soil organic carbon storage, soil quality and yield sustainability under sub humid and semiarid tropical India. Field Crops Research; 93: 264-280.

Mekonnen Asrat. 2005. Response and uptake of barley (Hordeum irregulare L.) to different rates of Orga-P and nitrogen fertilizers on Nitisols of Gozamin District, Ethiopia. MSc Thesis, Haramaya University, Ethiopia.

Melle Tilahun, Asfaw Azanaw and Getachew Tilahun. 2015. Participatory evaluation and promotion of improved food barley varieties in the highlands of north western Ethiopia. Wudpecker Journal of Agricultural Research; 4(3): 050 - 053.

Minale Liben, Alemayehu Assefa and Tilahun Tadesse. 2011. Grain yield and malting quality of barley in relation to nitrogen application at mid and high altitude in Northwest Ethiopia. Journal of Science and Development, 1(1): 75-88.

Mitiku Woldesenbet, Tamado Tana, Singh TN, Teferi M. 2014. Effect of integrated nutrient management on yield and yield components of food barley (Hordeum vulgare L.) in Kaffa Zone, Southwestern Ethiopia. Science Technology Arts Research Journal; 3(2):34-42.

Nayak, J.J., Vaidya, Dr .A.C. 2018. Green Manure in Crop Production and Soil Health. International Journal of Innovative Research in Science, Engineering and Technology; 7(6):2347-6710.

Ofosu-Anim J, Leitch M. 2009. Relative efficacy of organic manures in spring barley (Hordeum vulgare L.) production. Australian Journal of Crop Science; 3: 13-19.

Pandey A. K and Singh M. K. 2016. Importance and uses of green manuring in field crops. Rashtriya krishi; 11(2): $35-35$.

Rashid, A., Khan, U.K. and Khan, D.J. 2007. Comparative effect of varieties and fertilizer levels on barley (Hordeum vulgare L). Pakistan Journal of Soil Science; 1: 1-13.

Roberts, T. L. 2010. Nutrient best management practices: Western perspectives on global nutrient stewardship. In $19^{\text {th }}$ World Congress of Soil Science, Soil Solutions for a Changing World; 172-75, Brisbane, Australia.

Saidu A, Ole K, Leye BO. 2012. Performance of Wheat (Triticum aestivum L.) as influenced by complementary use of organic and inorganic fertilizers. International Journal of Science and Nature; 5:532-537.

Sepat RN, Rai RK, Shiva D (2010) Planting systems and integrated nutrient management for enhanced wheat (Triticum aestivum) productivity. Indian Journal of Agronomy; 55: 114-118.

Shahidur Rashid, Gashaw Abate, Solomon lemma, James Warner, Lulsegged Kasa and Nicholas Minot, 2015. Barley value chain in Ethiopia: research for Ethiopia agriculture policy analytical support for the Agricultural Transformation Agency (ATA).

Shiferaw Bokore and Anteneh Fikadu. 2014. Lime and NPK Effect on Soil Acidity and Yield of Barely in different Acid Soils of Southern Region, Ethiopia. International Journal of Natural Sciences Research; 2(7): 113122.

Tariku Beyene, Tolera Abera and Ermiyias Habte. 2018. Effect of Integrated Nutrient Management on Growth and Yield of Food Barley (Hordeum vulgare) Variety in Toke Kutaye District, West Showa Zone, Ethiopia. Advanced Crop Science Technology; 6: 365.

Tisdale LS, Nelson LW, Beaton DJ, Haulin JL. 2002. Soil Fertility and Fertilizers. Macmillan Publishing Company. New York, Toronto, Oxford and Singapore: 633.

Tolera Abera, Adamu Molla, Abraham Feyissa A. 2011. "Research achievements in barley cultural practices in Ethiopia," in Proceedings of the $2^{\text {nd }}$ National Barley Research and Development Review Workshop on Barley Research and Development in Ethiopia, pp. 113-126, HARC, Holetta, Ethiopia, ICARDA, Aleppo, Syria, 2011. 
Tolera Abera, Tolcha Tufa, Tesfaye Midega, Haji Kumbi, Bizuayehu Tola. 2018. Effect of Integrated Inorganic and Organic Fertilizers on Yield and Yield Components of Barley in Liben Jawi District. International Journal of Agronomy; 6:48-56.

Vanlauwe, B., Descheemaeker, K., Giller, K. E., Huising, J., Merckx, R., Nziguheba, G., Zingore, S. 2015. Integrated soil fertility management in sub-Saharan Africa: unravelling local adaptation. Soil; 1(1):491-508.

Wakene Tigre, Walelign Worku and Wassie Haile. 2014. Effects of nitrogen and phosphorus fertilizer levels on growth and development of barley (Hordeum vulgare L.) at Bore district, Southern Oromia, Ethiopia; 2(5): 260-266.

Woinshet Tamiru. 2007. Effect of nitrogen fertilizer levels on grain yield and malt quality of different malt barley (Hordeum vulgare L.) varieties in Shashemane woreda. MSc Thesis, Hawassa University, Hawassa, Ethiopia.

Woubshet Demissie, Selamyihun Kidanu, Cherukuri V Raghavaiah. 2017. Effect of integrated use of lime, blended fertilizer and compost on productivity, nutrient removal and economics of barley (Hordeum vulgare L.) on acid soils of high lands in West Showa Zone of Ethiopia. International Journal of Life Sciences; 5 (3): 311 322.

Yoshida, H., Nielsen, M. P., Scheutz, C., Jensen, L. S., Bruun, S., Christensen, T. H. 2016. Long-term emission factors for land application of treated organic municipal waste. Environmental Modeling and Assessment; 21(1), 111-124.

Zaccheo, P. V. C., Neves, C. S. V. J., de Cinque Mariano, D., Zorzenoni, T. O., Higashibara, L. R., Piccinin, G. G., \& Okumura, R. S. 2016. Green manure in fruticulture: Aspects on soil quality and use in agriculture. African Journal of Agricultural Research; 11(17):1469-1474. 